\title{
The use of green fluorescent protein (GFP) to select bovine embryos
}

\author{
A.M. Duszewska ${ }^{1}$, L. Kozikova ${ }^{3}$, H. Szydlik ${ }^{2}$ M. Cybulska ${ }^{1}$, \\ M. Korwin-Kossakowski ${ }^{1}$, B. Waś ${ }^{1}$, J. Połoszynowicz ${ }^{2}$, \\ K. Wicińska ${ }^{2}$ and S. J. Rosochacki ${ }^{2,4}$
}

\author{
Institute of Genetics and Animal Breeding, Polish Academy of Sciences, \\ ${ }^{l}$ Experimental Embryology Department \\ ${ }^{2}$ Molecular Cytogenetics Department \\ Jastrzębiec, 05-552 Wólka Kosowska, Poland \\ ${ }^{3}$ All Russian Research Institute for Farm Animal Genetics and Breeding \\ 55 a Moskovskoe shosse, St. Petersburg-Pushkin, 189620 Russia \\ ${ }^{4}$ Biatystok Technical University, Faculty of Building and Environmental Engineering, \\ Chair of Sanitary Biology and Biotechnology \\ Wiejska 45a, 15-351 Białystok, Poland
}

(Received 5 June 2002; revised version 21 October 2002; accepted 20 December 2002)

\begin{abstract}
A major factor limiting the transgenesis in domestic animals is the inefficiency of maintaining large numbers of recipients carrying nontransgenic foetuses. The objectives of this study were: 1 . to determine the influence of green fluorescent protein (GFP) construct injection on the development of bovine embryos, 2 . to identify and select the GFP positive bovine embryos, and 3 . to determine the rate of mosaicism in transgenic embryos. Cattle oocytes were matured and fertilised in vitro and zygotes were microinjected with pCX-EGFP construct consisting of CMV-IE enhancer, chicken $\beta$-actin promoter, cDNA of GFP (EGFP-732 bp) and rabbit $\beta$-globin polyadenylation sequences. Embryos from control (64) and microinjected (198) groups were cultured in vitro. After $168 \mathrm{~h}$ of culture, morula and blastocysts were observed in $39.06 \%$ of control and in $23.23 \%$ of injected group. We obtained three GFP positive embryos ( $1.51 \%$ of injected zygotes and $6.52 \%$ of morulae/blastocysts). One of them was 100 , second 75 and third $25 \%$ GFP positive ( $66.7 \%$ of mosaicism). Use of $g f p$ gene reporter to select bovine embryos is useful method to increase transgenic offspring, because GFP marker allows to choice only transgenic embryos and transfer them to recipients.
\end{abstract}

KEY WORDS: $g f p$ reporter gene, transgenic bovine embryos 


\section{INTRODUCTION}

Transgenic animals are very important for scientific, pharmaceutical and agriculture purposes. There are a lot of ways to insert heterologous recombinant DNA into the genome of living organism (Krimpenfort et al., 1991). One of the most important methods is pronuclear microinjection that has been used for successful generation of transgenic mammalian species, such as: mice, rats, rabbits, pigs, sheep, goats and cattle (Wall, 1997).

Microinjection of DNA into the pronuclei of one-cell embryos work very well in mice, but it remains inefficient and expensive in domestic animals. In large domestic animals, this approach generates 0.02 to $2 \%$ of transgenic offspring from microinjected zygotes (Cousens et al., 1994) but in cattle less than 1\% (Chen et al., 1999). There are several limitations to this approach: 1 . a large number of recipients need to be maintain through the gestation period, 2. a low efficiency of transgene incorporation, 3. a requirement for a large number of oocytes for microinjection. These make the production of transgenic animals, especially cows, extremely difficult and expensive (Wall, 2002).

Preselection of transgenic embryos before transfer into the surogate recipient is the way to reduce the cost of transgenic cattle production. This may be achieved by reporter gene technology as their gene products are easy detectable, with low background activities from endogenous gene products. The ectopic levels of reporter gene expression have no adverse effects on either the physiology or development of the individual cell.

At present, many authors have used the reporter gene technique in the preimplantation-stage screening protocol of many species of animals produced via pronuclear microinjection (Ikawa et al., 1995; Takada et al., 1997; Kato et al., 1999). This procedure allows the identification of presumptive transgenic embryos that can be transferred into surrogate recipients, thereby increasing the overall efficiency and reducing the cost of transgenic animal production (Keiser et al., 2001).

A number of reporter genes have been used: Escherichia coli $\beta$-galactosidase gene (lacZ) (Connolly et al., 1994); chloramphenicol acetyltransferase - (cat) (Gorman et al., 1982); firefly luciferase (luc), (De Wet et al., 1987) and horseradish peroxidase (Connolly et al., 1994).

One of the most important reporter genes that can be used in preimplantationstage screening protocols is the green fluorescent protein $(g f p)$ from the jellyfish (Aequorea Victoria), which, when expressed in either eukaryotic or prokaryotic cells and illuminated by blue or UV light, yields a bright green fluorescence (Chalfie et al., 1994; Baumann et al., 1998). It has been recently suggested that green fluorescent protein (GFP) may be a good and convenient detection system for transgenesis in intact living cells and organisms. GFP may "open the door" as a fusion tag to monitor protein localization within the living cells (Cubitt et al., 1995). 
There are a number of advantages of GFP transgenic embryos. Among these is the production of therapeutic specific proteins in milk or urine (Chalfie et al., 1994; Chiocchetti et al., 1997; Zhou et al., 1997; Baumann et al., 1998) and the labelling of some specific tissues such as the ureteric bud (Srinivas et al., 1999). GFP can also be used as a biomarker for selection of transfected cells (Chan et al., 1999; Arat et al., 2001).

The objectives of the present research were: 1 . to determine the influence of $g f p$ construct injection on the development of bovine embryos, 2. to identify and select the GFP-positive bovine embryos, and 3. to determine the rate of mosaicism in transgenic embryos.

\section{MATERIAL AND METHODS}

In vitro maturation of bovine oocytes

The cumulus-oocyte complexes (COCs) were collected from bovine ovaries which were obtained from a slaughterhouse and matured in TCM199 buffered with Hepes $25 \mathrm{mM}$ supplemented with $10 \%$ heat-inactivated FBS, $0.02 \mathrm{IU} / \mathrm{ml} \mathrm{pFSH}$ (Sigma), $1 \mu \mathrm{mg} / \mathrm{ml} 17 \beta$-estradiol (Sigma), $0.2 \mathrm{mM}$ sodium pyruvate (Merck) and 50 $\mu \mathrm{mg} / \mathrm{ml}$ gentamicin sulphate. Twenty immature cumulus-oocytes complexes were placed in one well of a 4-well culture dish (Nunc) and cultured in $450 \mu \mathrm{I}$ TCM 199 supplemented solution for $24 \mathrm{~h}$ in $38.5^{\circ} \mathrm{C}, 5 \% \mathrm{CO}_{2}$ in humidified air (Marguant-Le Guienne et al., 1989).

In vitro fertilization of bovine oocytes

Spermatozoa obtained from a single bull were prepared by swim-up procedure according to the method of Marguant-Le Guienne et al. (1989). Ten matured oocytes after being washed in fertilization medium were placed in 4-well culture dishes in $450 \mu \mathrm{ml}$ Fert-TALP medium supplemented with $6 \mathrm{mg} / \mathrm{ml}$ BSA FAF, $0.2 \mathrm{mM}$ sodium pyruvate, $50 \mu \mathrm{mg} / \mathrm{ml}$ gentamicin sulphate, $20 \mu \mathrm{mM}$ penicillamine (Sigma), $10 \mu \mathrm{mM}$ hypotaurine (Sigma), $1 \mu \mathrm{mM}$ epinephrine (Sigma) and $2 \mu \mathrm{mg} / \mathrm{ml}$ heparin (Sigma). The COCs and spermatozoa were adjusted to a final concentration of $1 \times 10^{6} / \mathrm{ml}$ and were co-cultured for $24 \mathrm{~h}$ at $38.5^{\circ} \mathrm{C}$ in $5 \% \mathrm{CO}_{2}$ of humidified air (Parrish et al., 1986).

Microinjection gfp gene construct into bovine zygotes

After $24 \mathrm{~h}$ of culture, the presumptive zygotes were washed 3 times in TCM-199 buffer (supplemented with Hepes $25 \mathrm{mM}, 50 \mu \mathrm{g} / \mathrm{ml}$ gentamicin sulphate, $100 \mathrm{IU}$ 


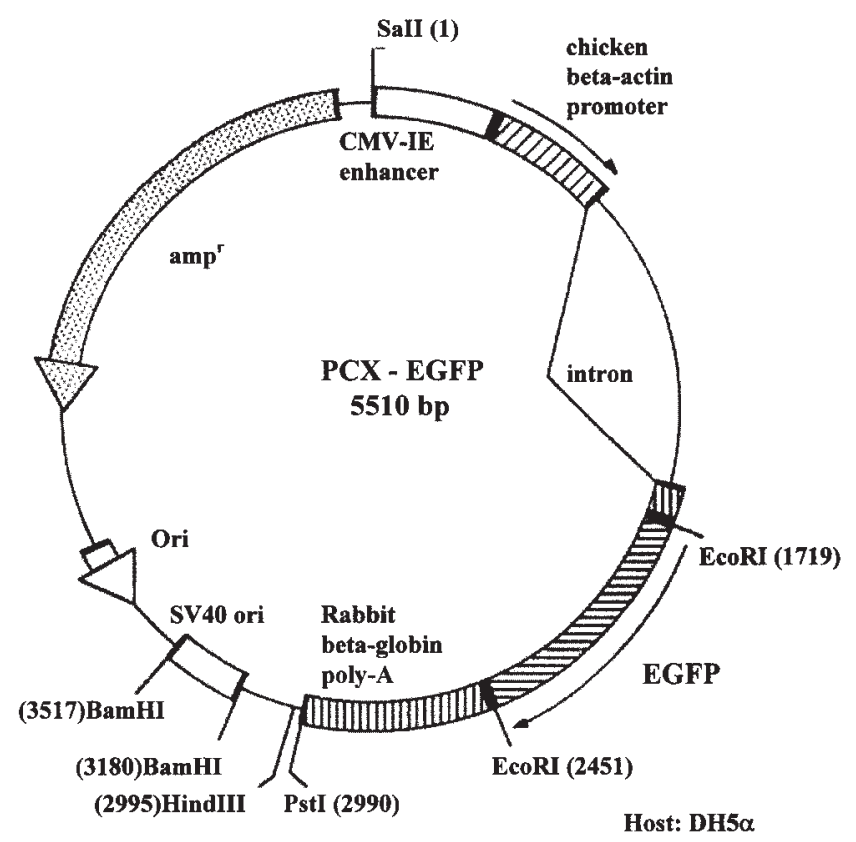

Figure 1. Construction of pCX-EGFP transgene. pCX-EGFP (5510 bp) contains the CMV-IE enhancer, chicken beta-actin promoter, cDNA of EGFP, and rabbit beta-globin poly-A signal

penicillin, $50 \mu \mathrm{g} / \mathrm{ml}$ streptomycin) and then were centrifuged at $12000 \mathrm{xg}$ for $6 \mathrm{~min}$ in order to visualize the pronuclei. Zygotes were then transfered to a $3 \mathrm{~cm}$ Petri dish into a drop of TCM-199 buffer (containing $25 \mathrm{mM}$ Hepes, $50 \mu \mathrm{g} / \mathrm{ml}$ gentamicin sulphate, $100 \mathrm{IU}$ penicillin, $50 \mu \mathrm{g} / \mathrm{ml}$ streptomycin) and covered with mineral oil (Sigma). The dish with the zygotes was placed under the Nikon Inverted Microscope with Nomarski contrast optics. Injection of DNA solution was conducted manually using a fine glass pipette into the male pronucleus; the time of injection was noted by observing the swelling of the pronucleus. The transgene construct, pCX-EGFP, (gift of Professor M. Okabe, Ossaka University, Japan) used in the present study is shown in Figure 1. It consists of CMV-IE enhancer, chicken $\beta$-actin promoter, cDNA of GFP (EGFP) (732 bp) and rabbit $\beta$-globin polyadenylation sequences. The pCX-EGFP transgene was diluted to a concentration of $5.0 \mathrm{ng} / \mu 1$ and used for pronuclear microinjection into bovine zygotes at $24 \mathrm{~h}$ post insemination.

In vitro culture of bovine embryos

Embryos from control and microinjected groups were co-cultured with Vero/BRL cell monolayers in $40 \mu \mathrm{l}$ of Menezo B-2 medium (ART of CCD) plus 10\% heat 
inactivated FBS under mineral oil up to $168 \mathrm{~h}$ after insemination at $38.5^{\circ} \mathrm{C}$ in $5 \%$ $\mathrm{CO}_{2}$ of incubator. The culture medium was renewed twice during this time. After $48 \mathrm{~h}$ of culture, $20 \mu \mathrm{l}$ of medium was removed and $20 \mu \mathrm{l}$ of fresh Menezo B-2 medium supplemented with $10 \%$ FBS was added but after $144 \mathrm{~h}$ of culture, $20 \mu \mathrm{l}$ of medium was removed and $20 \mu \mathrm{l}$ of Menezo B 2 was added (Duszewska et al., 2000).

Fluorescence analysis of GFP expression in bovine embryos

Expression of GFP in embryos was detected after $168 \mathrm{~h}$ of culture by a standard fluorescein isothiocyanate (FITC) filter for developmental stages and GFP expression using excitation in $488 \mathrm{~nm}$. The transgenic embryos were scored for GFP positive blastomeres within an embryo.

\section{RESULTS AND DISCUSSION}

The influence of gfp construct injection on the development of bovine embryos

The development injected and non-injected (control) bovine embryos are presented in Table 1. In this study, in total two hundred and sixty two bovine zygotes were used. One hundred and ninety eight were injected with the $g f p$ transgene and sixty four served as a control. After $48 \mathrm{~h}$ of culture, $47.98 \%$ of the zygotes from the injected group cleaved compared with $81.25 \%$ for the control group. After $168 \mathrm{~h}$ of culture, a higher percentage of morulae and blastocysts were observed in the control $(39.06 \%)$ than in injected group (23.23\%). Corresponding results for our previous studies were 44 and 32.2\% (Duszewska et al., 2000; Rosochacki et al., 2001). The greater negative effect on embryo development in the present study may be due to the increase in microinjected DNA concentration ( $3 \mathrm{ng}$ in our previous study vs $5 \mathrm{ng}$ in this one), an observation that was also shown by Behboodi et al. (2001). It should be pointed out, that the development of compacted morulae and blastocysts from $48 \mathrm{~h}$ cleaved embryos was very similar, being $48 \%$ in both groups. The efficiency in producing morulae/blastocysts after a pronuclear injection was lower $(23.23 \%)$

TABLE 1

In vitro development of microinjected (GFP-positive) and non-injected (control) bovine embryos

\begin{tabular}{lcccc}
\hline Groups & $\begin{array}{c}\text { No of zygotes/ } \\
\text { No of injected } \\
\text { zygotes }\end{array}$ & $\begin{array}{c}\text { No of cleaved } \\
\text { embryos } \\
\%\end{array}$ & $\begin{array}{c}\text { No of } \\
\text { morulae/blastocysts } \\
\text { development } \\
\%\end{array}$ & $\begin{array}{c}\text { No of } \\
\text { GFP positive } \\
\text { embryos after 168 h } \\
\%\end{array}$ \\
\hline Injected & $198 / 198$ & $95(47.98)$ & $46(23.23)$ & $3(1.52)$ \\
Control & $64 / 0$ & $52(81.25)$ & $25(39.06)$ & 0 \\
\hline
\end{tabular}


than in our previous results, but comparable with other authors, who obtained an efficiency in producing blastocysts between 5 and 24\% (Krimpenfort et al., 1991; Wall and Seidel, 1992; Bowen et al., 1994; Chan et al., 1999; Ideta et al., 2002). A higher percentage of morulae and blastocysts was obtained by Wang et al. (2001) but they also obtained a higher percentage of viable zygotes after injection (83\%). The yield of morulae/blastocysts resulting from 1-cell in vivo derived embryos that had survived microinjection could have been even 50\% higher than from equivalent in vitro-derived embryos (Krimpenfort et al, 1991; Behboodi et al., 1993; Behboodi et al., 2001). In our work we used only in vitro derived oocytes.

\section{The identification and selection of the GFP positive bovine embryos}

The majority of transgenic animals generated by pronuclear microinjection appear to be mosaic in both somatic cells and germ cells for the pattern of DNA integration (Wall, 1966). Three pronuclear microinjection experiments were performed using the pCX-EGFP gene construct (Figure 1). The coding sequence for enhanced GFP expression (EGFP, Ossaka, Japan) was fused to the chicken $\beta$-actin promoter and $\beta$-globin polyadenylation sequences, and this construct was used to produce transgenic bovine embryos. Embryos were diagnosed as GFP positive by visual assessment if the level of fluorescent emission was greater than that detected due to autofluorescence from the noninjected group (Figure 2).

The bovine embryos were detected for green fluorescence after $168 \mathrm{~h}$ as the expression of transcription events occurs later in bovine embryos than in other species (mouse, rabbits), and also the bovine embryos are much more sensitive to environmental conditions than the others (our unpublished results). In the mouse, the transcription occurs in two-cell embryos as well as expression of microinjected DNA into the pronuclei (Brinster et al., 1982; Stevens et al., 1989). This indicates that promoter function during early embryogenesis as well as transcriptional activity first appears with the formation of the zygotic nucleus (Martinez-Salas et al., 1989). However, not many attempts have been made to determine the precise timing of bovine gene expression after DNA microinjection.

In this experiment after $168 \mathrm{~h}$ the green fluorescent appeared in 3 embryos out of 198 injected zygotes, which constitutes $1.51 \%$ of transgenesis and $6.52 \%$ of morulae/blastocyst transgenic embryos.

The overall efficiency in producing live transgenic cattle is reported to be less than $1 \%$ of the total number of microinjected embryos (Brem, 1993; Brem and Muller, 1993; Wall, 1996), but a lot of them could be mosaics, so the efficiency of producing $100 \%$ transgenic animals is much lower and ranges from 0.038 to $0.22 \%$ (Chen et al., 1999). Takeda et al. (1997) obtained $10 \%$ of embryos expressing blastocyst-stage GFP. A high percentage was also obtained by Wang and al. (2001), who used cytomegalovirus promoter (CMV). In our experiment the chicken 

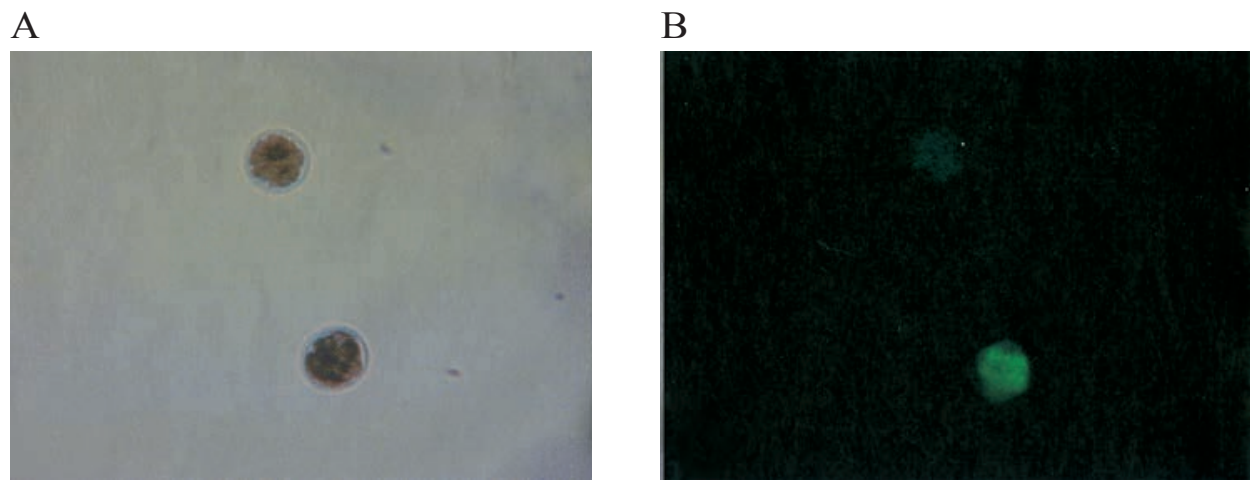

Figure 2. The bovine embryos injected with pCX-CGFP; a-two embryos were viewed under light microscopy, b-two embryos were viewed under UV light microscopy, one of them was GFP positive

$\beta$-actin promoter was used. According to Nakamura et al. (1998) this promoter, with its luciferase reporter gene was expressed more intensively in bovine morulae and blastocysts than gene constructs consisting of thymidine kinase with SV40 early promoters. From three transgenic embryos, one embryo was $100 \%$ GFP positive. This means that the pCX-EGFP gene construct was integrated during the first cell cycle before DNA replication. In our previous report (Rosochacki et al., 2001 ) we got no $100 \%$ transgenic embryos and only 5 mosaic ones. The category of $100 \%$ transgenic embryos was $0.50 \%$ of the injected zygotes and $2.17 \%$ of the morulae/blastocysts. This low percent of $100 \%$ category in the transgenesis may be caused by various factors: nature of the DNA construct or DNA fragment preparation, timing of microinjection and the nature of microinjected embryos (maturation in vitro).

In the work of Behboodi et al. (2001) 2578 in vitro fertilized 1-cell embryos were microinjected but no transgenic calves were born. However, they did obtained one transgenic bull calf from the microinjection 8193 of two-cell in vivo fertilized embryos. They have shown that the new-born bull was transgenic. One possible explanation is that only one blastomere was a founder of the transgenic offspring (the other was destroyed) or that the transgenic calf was mosaic but not for the tissues that were examined. These results emphasize the enormous inefficiency associated with the generation of transgenic cattle by simple microinjection. Thus the alternative strategy based on the use of reporter genes and nuclear transfer of transfected somatic cells could be more appropriate.

\section{The incidence of mosaicism in transgenic embryos}

In this experiment we obtained two mosaic embryos after $g f p$ gene injection. One of them was $75 \%$ GFP positive and one was $25 \%$ GFP positive. In our previous 
work (Rosochacki et al., 2001), 5 mosaic embryos were obtained. These comprised $25-75 \% g f p$ incorporation. This could be caused by late integration of transgene during embryonic preimplantation development (Wall and Seidel, 1992).

Mosaicism in transgenic animals produced by pronuclei microinjection was first recognised when offspring derived from transgenic founder mice were found to be nontransgenic (Palmiter et al., 1984). In transgenic mosaic animals, not all the body cells contain the transgene, as DNA integration into the genome occurs randomly and segregation of the transgene into cells is mosaic in most cases. It can be seen in uneven distribution and expression of transgene in different tissues or by the failure to transmit the transgene to offspring (Palmiter et al., 1984; Evans et al., 1994). Also, because of the existence of episomal transgenes, not all of those embryos expressing the reporter gene are transgenic (Muramatsu and Nakamura, 1997). Wall (1997) also points out that because plasmids may remain unincorporated into the genome and can segregate during cell division (producing mosaic embryos), that the ideal $g f p$ reporter would somehow signal its incorporation into the genome. Of various strategies that have been used to identify transgenic/mosaic embryos prior to transfer to the recipients (Bowen et al., 1994; Ikawa et al., 1995; Chan et al., 1999) none preclude the identification of false positives due to the persistence of non-integrated microinjected DNA until the late stages of development. The loss of potential transgenic offspring may be due to the false negatives in transgenic mosaicism. This is a very important problem to the application of transgenic technology in livestock (Wall, 1997). Therefore, the current procedure that simplifies the detection of transgenic embryos would be very useful in establishing transgenic lines of animals, particularly cows. GFP would be useful as a marker of gene expression, particularly in embryogenesis, since the observation of live embryo is a direct monitoring of gene expression. Reporter $g f p$ together with structural gene of interest and proper promoter could be a promising to get large bioreactors.

\section{CONCLUSIONS}

Our results support the idea that the use of $g f p$ gene reporter to select transgenic bovine embryos could be a useful method to increase the efficiency of production of transgenic offspring by ensuring that only transgenic embryos are transferred to recipient animals. The other, not $100 \%$ transgenic embryos might be served as a donors of transgenic cells after disaggregation, which can also be used through cloning procedure to get more $100 \%$ transgenic embryos and transfer them also to the recipients to produce only transgenic animals. 


\section{REFERENCES}

Arat S., Rzucidlo S.J., Gibbson J., Miyoshi K., Stice S.L., 2001. Production of transgenic bovine embryos by transfer of transfected granulosa cells into enucleated oocytes. Development 60, 20-26

Baumann C.T., Lim C.S., Hager G.L., 1998. Simultaneous visualisation of the yellow and green forms of the green fluorescent protein in living cells. J. Histochem. Cytochem. 46, 1073-1076

Behboodi E., Anderson G. B., Horvat S., Medrano J. F., Murra Y.J. D., Rowe J. D., 1993. Microinjection of bovine embryos with a foreign gene and its detection at the blastocyst stage. J. Dairy Sci. 76, 3392-3399

Behboodi E., Groen W., Destrempes M.M., Williams J.L., Ohlrichs C., Gavinn W.G., Broek D.M., Ziomek C.A., Faber D.C., Meade H.M., Echelard Y., 2001. Transgenic production from in vivoderived embryos: Effect on calf birth weight and sex ratio. Mol. Reprod. Dev. 60, 27-37

Bowen R.A., Reed M.L., Schnieke A., Seidel G.E. Jr., Stacey A., Thomas W.K., Kajikawa O., 1994. Transgenic cattle resulting from biopsed embryos: Expression of c-ski in a transgenic calf. Biol. Reprod. 50, 664-668

Brem G., 1993. Transgenic animals. In: A. Puhler (Editor). Genetic Engineering of Animals. VCH Publishers, New York, pp. 84-170

Brem G., Muller M., 1994. Large transgenic mammals. In: N. Maclean (Edtor). Animal with Novel Genes. Cambridge University Press, Cambridge, pp. 179-244

Brinster R. L., Chen H. Y., Warren R., Sarhy A., Palmiter R. D., 1982. Regulation of metallothionein-tymidine kinase fusion plasmids injected into mouse eggs. Nature 296, 39-42

Chalfie M., Tu Y., Euskirchen G., Ward W.W., Prasher D.C., 1994. Green fluorescent protein as a marker for gene expression. Science 263, 802-805

Chan A.W.S., Kukolj G., Skalka A.M., Bremel R.D., 1999. Timing of DNA integration, transgenic mosaicism, and pronuclear microinjection. Mol. Reprod. Dev. 52, 406-413

Chen R., Greene E.L., Colinsworth G., Grewal J.S., Houghton O., Zeng H., Garnovskaya M., Paul R.V., Raymond J.R., 1999. Enrichment of transiently transfected mesangial cells by cell sorting after cotransfection with GFP. Amer. Physiol. 276, 777-785

Chiocchetti A., Tolosano E., Hirsch E., Silengo L., Altruda F., 1997. Green fluorescent protein as a reporter of gene expression in transgenic mice. BBA-Gene Struct. Express. 1352, 193-202

Connolly C.N, Futter C. E., Gibson A., Hopkins C. R., Cutler D.F., 1994. Transport into and out of the Golgi complex studied by transfecting cells with cDNA encoding horseradish peroxidase. J. Cell. Biol. 127, 641-652

Cousens C., Carver A.S., Wilmut I., Colman A., Garner I., O’Neill G.T., 1994. Use of PCR-based methods for selection of integrated transgenes in preimplantation embryos. Mol. Reprod. Differ. 39, 384-391

Cubitt A.B., Heim R., Adams S.R., Boyd A.E., Gross L.A., Tsien R.Y., 1995. Understanding improving and using green fluorescent proteins. Trends Biochem. Sci. 20, 448-455

De Wet J. R., Wood K.V., Deluca M., Helsinki D.R., Subramani S., 1987. Firefly luciferase gene: structure and expression in mammalian cells. Mol. Cell. Biol. 7, 725-737.

Duszewska A.M., Reklewski Z., Pieńkowski M., Karasiewicz J., Modliński J.A., 2000. Development of bovine embryos on Vero/BRL cell monolayers (mixed co-culture). Theriogenology 54, 1239-1247

Evans M.J., Gilmour D.T., Colledge W.H., 1994. Transgenic rodents. In: N. Maclean (Editor). Animal with Novel Genes. Cambridge University Press, Cambridge, pp. 138-178

Gorman C.M., Moffat L.F., Howard B.H., 1982. Recombinant genomes which express chloramphenicol acetyltransferase in mammalian cells. Mol. Cell. Biol. 2, 1044-1051 
Ideta A., Konishi M., Urakawa M., Uruno K., Aoyagi Y., Okabe M., Funahashi H., 2002. An efficient method to produce transgenic cattle by using microinjection with an EGFP-reporter and nuclear transfer. Theriogenology 55, 522 (Abstr.)

Ikawa M., Kominami K., Yoshimura Y., Tanka K., Nishimune Y., Okabe M., 1995. A rapid and noninvasive selection of transgenic embryos before implantation using green fluorescent protein (GFP). FEBS Lett. 375, 125-128

Kato M., Yamnouchi K., Ikawa M., Okabe M., Naito K., Tojo H., 1999. Efficient selection of transgenic mouse embryos using EGFP as a marker gene. Mol. Reprod. Dev. 54, 43-48

Keiser J.T., Jobst P.M., Garst A.S., Boone J.T., Geyer Ch.B., Phelps C., Ayares D.L., Page R.L., 2001. Preimplantation screening for transgenesis using an embryonic specific promoter and Green Fluorescent Protein. Cloning 3, 23-30

Krimpenfort P., Rademakers A., Eyestone W., Van de Achans A., Van de Broek S., Koiman P., Kootwijk E., Platenbury G., Pieger F., Strijker R., de Boer H., 1991. Generation of transgenic cattle using in vitro embryo production. Biotechnology 9, 844-847

Marguant-Le Guienne B., Gerard M., Solari A., Thibault C., 1989. In vitro culture of bovine eggs fertilised either in vivo or in vitro. Reprod. Nutr. Develop. 29, 559-568

Martinez-Salas E., Linney E., Hassell J., Depamphilis M.L., 1989. The need for enhancers in gene expression first appears during mouse development with formation of the zygotic nucleus. Gene Develop. 3, 1493-1506

Muramatsu T., Nakamura A., 1997. Production of transgenic cattle as an animal bioreactor: Current status and perspective. Trend Comp. Biochem. Physiol. 3, 9-21

Nakamura A., Okumura J.I., Muramatsu T., 1998. Quantitative analysis of Luciferase activity of viral and hybrid promoters in bovine preimplantation embryos. Mol. Reprod. Dev. 49, 368-373

Palmiter R.D., Wilkie T.M., Chen H.Y., Brinster R.L., 1984. Transmission distortion and mosaicism in an unusual transgenic mice pedigree. Cell 36, 869-877

Parrish J.J., Susko-Parrish J.L., Leibfried-Rutledge M.L., Critse E.S., Eyestone W.H., First N.L., 1986. Bovine in vitro fertilisation with frozen-thawed semen. Theriogenology 25, 591-600

Rosochacki S.J., Duszewska A.M., Kozikova L., Olszewski R., 2001. Expression of GFP in microinjected bovine embryos. Anim. Sci. Pap. Rep. 19, 193-202

Srinivas S., Goldberg M.R., Watanabe T., D’Agati V., Al-Awqati Q., Costanini F., 1999. Expression green fluorescent protein in the ureteric bud of transgenic mice: A new tool for the analysis of ureteric bud morphogenesis. Develop. Genetics 24, 241-251

Stevens M. E., Meneses J. J., Pedersen R. A., 1989. Expression of a mouse metallothionein - Escherichia coli $\beta$-galactosidase fusion gene (MT- $\beta$ gal) in early mouse embryos. Exp. Cell Res. $183,319-325$

Takada T., Iida K., Awaji T., Itoh K., Takahashi R., Shibui A., Yoshida K., Sugano S., Tsujimoto G., 1997. Selective production of transgenic mice using green fluorescent protein as a marker. Nat. Biotechnol. 15, 458-461

Wall R.J., 1996. Transgenic livestock: progress and prospects for the future. Theriogenology 45, 57-68

Wall R.J., 1997. A new lease on life for transgenic livestock. Nat. Biotechnol. 15, 416-417

Wall R.J., 2002. New gene transfer methods. Theriogenology 57,189-201

Wall R.J., Seidel G.E. Jr., 1992. Transgenic farm animals: a critical analysis. Theriogenology 38, 337-357

Wang B., Lazaris A., Lindenbaum M., Stewart S., Co D., Perez C., Drayer J., Karatzas C.N., 2001. Expression of a reporter gene after microinjection of mammalian artificial chromosomes into pronuclei of bovine zygotes. Mol. Reprod. Dev. 60, 433-438

Zhou L., Sun B., Zhang C.L., Fine A., Chiu S.Y., Messing A., 1997. Live astrocytes visualized by green fluorescent protein in transgenic mice. Develop. Biol. 187, 36-42 


\section{STRESZCZENIE}

\section{Wykorzystanie GFP do selekcji zarodków bydlęcych}

Celem badań było: 1. zbadanie wpływu mikroiniekcji genu reporterowego gfp na rozwój zarodków bydlęcych, 2. identyfikacja i selekcja GFP pozytywnych zarodków, oraz 3. określenie odsetka zarodków mozaikowych. Oocyty izolowano z jajników od ubitych w rzeźni krów. Dojrzewanie i zapłodnienie prowadzono w warunkach in vitro. Do uzyskanych zygot wprowadzano gen pCX-EGFP, złożony z enhancera CMV-IE, promotora beta-aktyny kury, cDNA białka GFP i sygnału poliadenylacji pochodzącego z beta-globiny królika. Zarodki z grupy kontrolnej (64) i grupy doświadczalnej (198) były hodowane in vitro. Po 168 godzinnej hodowli, w grupie kontrolnej uzyskano 39,06\% zarodków w stadium moruli i blastocysty, natomiast w grupie doświadczalnej 23,23\%. Uzyskano 3 zarodki GFP pozytywne $(1,51 \% \mathrm{w}$ stosunku do zygot po mikroiniekcji oraz $6,52 \% \mathrm{w}$ stosunku do morul i blastocyst). Jeden z zarodków był w 100, jeden w 75 i jeden w 25\% GFP pozytywny; mozaicyzm wynosił $66,7 \%$. Wykorzystanie genu reporterowego gfp pozwala na wczesną selekcję zarodków bydlęcych i przeniesienie tylko transgenicznych zarodków do biorczyń, co ma ogromne znaczenie w uzyskaniu w pełni transgenicznego potomstwa i znacznego obniżenia kosztów transgenezy. 